\title{
The Membrane Properties of Cochlear Root Cells are Consistent with Roles in Potassium Recirculation and Spatial Buffering
}

\author{
Daniel J. Jagger ${ }^{1}$, Graham Nevill ${ }^{1}$, And Andrew Forge ${ }^{1}$ \\ ${ }^{1}$ Centre for Auditory Research, UCL Ear Institute, University College London, 332 Gray's Inn Road, London, WC1X 8EE, UK
}

Received: 18 February 2010; Accepted: 24 March 2010; Online publication: 15 April 2010

\begin{abstract}
Auditory transduction, amplification, and hair cell survival depend on the regulation of extracellular $\left[\mathrm{K}^{+}\right]$ in the cochlea. $\mathrm{K}^{+}$is removed from the vicinity of sensory hair cells by epithelial cells, and may be distributed through the epithelial cell syncytium, reminiscent of "spatial buffering" in glia. Hypothetically, $\mathrm{K}^{+}$is then transferred from the epithelial syncytium into the connective tissue syncytium within the cochlear lateral wall, enabling recirculation of $\mathrm{K}^{+}$ back into endolymph. This may involve secretion of $\mathrm{K}^{+}$from epithelial root cells, and its re-uptake via transporters into spiral ligament fibrocytes. The molecular basis of this secretion is not known. Using a combination of approaches we demonstrated that the resting conductance in guinea pig root cells was dominated by $\mathrm{K}^{+}$channels, most likely composed of the Kir4.1 subunit. Dye injections revealed extensive intercellular gap junctional coupling, and delineated the root cell processes that penetrated the spiral ligament. Following uncoupling using 1-octanol, individual cells had $\mathrm{Ba}^{2+}$-sensitive weakly rectifying currents. In the basal (high-frequency encoding) cochlear region $\mathrm{K}^{+}$loads are predicted to be the highest, and root cells in this region had the largest surface area and the highest current density, consistent with their role in $\mathrm{K}^{+}$secretion. Kir4.1 was localized within root cells by immunofluorescence, and specifically to root cell process membranes by immunogold labeling. These results support a role for root cells in cochlear $\mathrm{K}^{+}$regulation, and suggest that
\end{abstract}

Correspondence to: Daniel J. Jagger - Centre for Auditory Research, UCL Ear Institute - University College London - 332 Gray's Inn Road, London, WC1X 8EE, UK. Telephone: +44 (0)20 7679 8930; fax: +44 (0) 207679 8990; email: d.jagger@ucl.ac.uk channels composed of Kir4.1 subunits may mediate $\mathrm{K}^{+}$ secretion from the epithelial gap junction network.

Keywords: deafness, gap junctions, inward rectifier, Kir4.1, spiral ligament, stria vascularis

\section{INTRODUCTION}

The sensitivity and frequency selectivity of mammalian auditory transduction depends on a number of homeostatic mechanisms that regulate the availability of $\mathrm{K}^{+}$in the cochlear fluids (Hibino and Kurachi 2006; Mistrik et al. 2009; Wangemann 2006). The ionic composition of endolymph and the magnitude of the endocochlear potential (EP) in scala media are both regulated by stria vascularis (Nin et al. 2008; Souter and Forge 1998). Experimental evidence from in vivo studies has suggested that $\mathrm{K}^{+}$in endolymph is sourced from perilymph, rather than from the blood supply (Wada et al. 1979). This observation led to a hypothesis of a recirculation of $\mathrm{K}^{+}$through the cochlear tissues (Hibino and Kurachi 2006; Kikuchi et al. 2000; Kikuchi et al. 1995; Wangemann 2006; Zhao et al. 2006), which is summarized in Figure 1.

During auditory transduction $\mathrm{K}^{+}$exits into the perilymph via voltage-gated channels in the basolateral membrane of hair cells (Johnstone et al. 1989; Mammano and Ashmore 1996). Accumulation of $\mathrm{K}^{+}$in the vicinity of hair cells is prevented by transporters expressed by underlying epithelial supporting cells (Boettger et al. 2002; Boettger et al. 2003; Hibino and Kurachi 2006). Supporting cells are contained within the epithelial gap junction network (Fig. 1A), and this network conducts $\mathrm{K}^{+}$derived from 
A
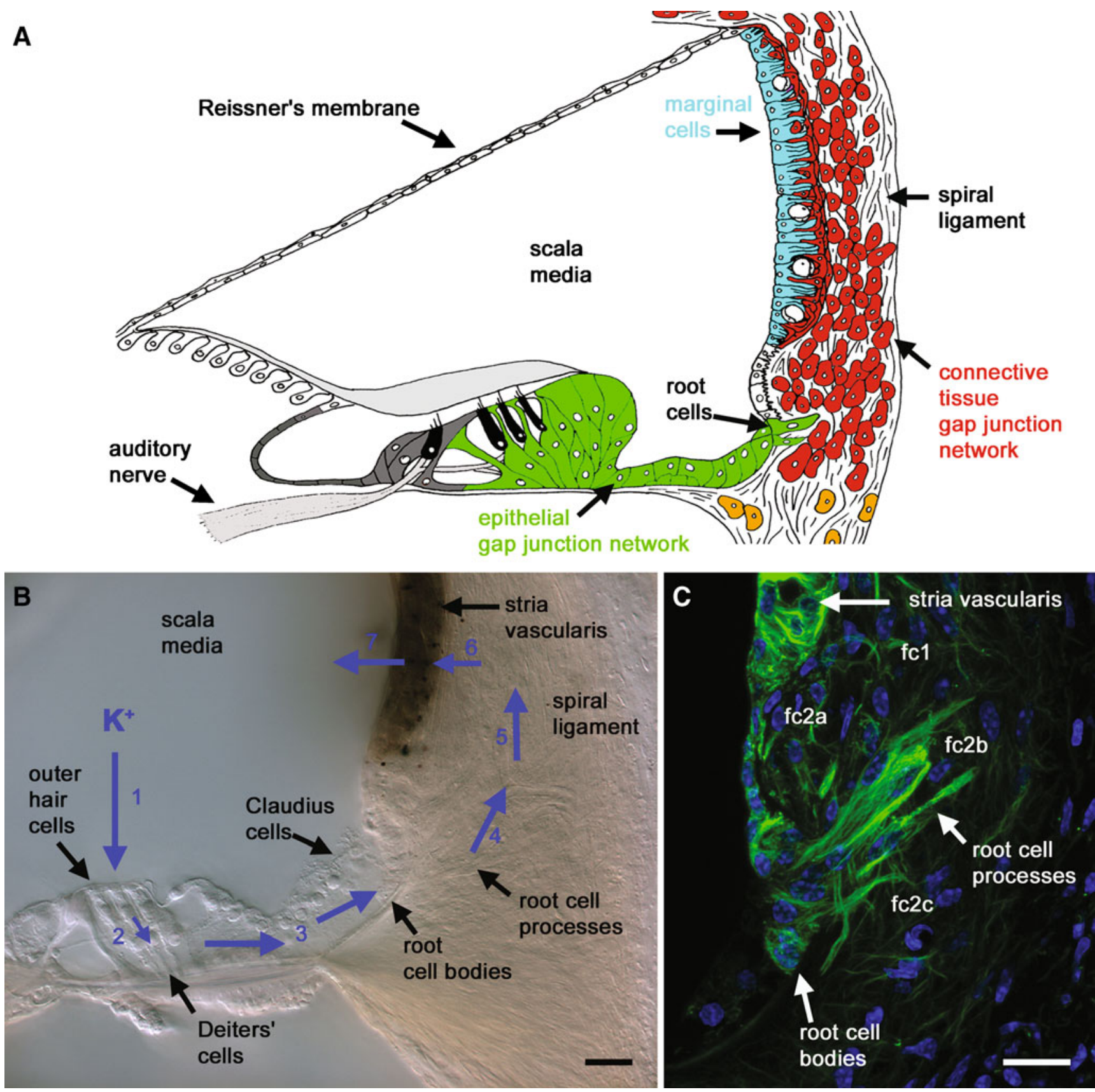

FIG. 1. Root cells may play roles in cochlear $\mathrm{K}^{+}$recirculation and spatial buffering. A A schematic representation of the major tissues involved in $\mathrm{K}^{+}$homeostasis in the mammalian cochlea. There are two distinct groups of coupled cells, the epithelial gap junction network (green) and the connective tissue gap junction network (red). The epithelial network is composed of supporting cells in the organ of Corti, and root cells. The connective tissue network is composed of spiral ligament fibrocytes, coupled to basal cells and intermediate cells in stria vascularis. Strial marginal cells (pale blue) are electrically isolated from the connective tissue network. Endolymph fills scala media. The high $\left[\mathrm{K}^{+}\right]$of endolymph bathes the stereociliary bundles on the apical pole of hair cells (black). B Differential interference contrast photomicrograph of a fixed vibratome section of the guinea pig cochlea turn 2, identifying the hypothesized lateral $\mathrm{K}^{+}$recirculation pathway (shown by blue arrows). During auditory mechano-transduction $\mathrm{K}^{+}$from endolymph enters outer hair cells (1), then $\mathrm{K}^{+}$exits the basolateral membrane of outer hair cells and is siphoned by the underlying Deiters' cells (2). $\mathrm{K}^{+}$is carried within the epithelial cell gap junction network (3), via Claudius cells and into the cell bodies of root cells. $\mathrm{K}^{+}$is transferred by an as yet undetermined mechanism from the root cells, and into spiral ligament fibrocytes (4), and is carried between fibrocytes via gap junctions (5), before its return to basal cells and intermediate cells in stria vascularis (6), and its re-secretion by marginal cells into the endolymph within scala media (7). C Root cells identified within a confocal image projection of anti-acetylated tubulin immunofluorescence (green), labeling intracellular microtubules. Microtubules were concentrated within root cell processes invading the spiral ligament, and within marginal cells of stria vascularis. Root cell processes were directed towards type 2a fibrocytes $\left(f_{c} 2 a\right)$ in the spiral prominence, to type $2 \mathrm{~b}$ fibrocytes $\left(f_{c} 2 b\right)$ behind the spiral prominence, and type $2 \mathrm{c}$ fibrocytes $\left(f_{c} 2 \mathrm{C}\right)$ in the more inferior region of spiral ligament. Nuclei were stained with DAPI (blue). Scale bars B and $\mathbf{C}=20 \mu \mathrm{m}$. 
outer hair cells back to the cochlear lateral wall via a cytoplasmic gap junctional intercellular pathway (Hibino and Kurachi 2006). For complete recirculation to occur (Fig. 1B), $\mathrm{K}^{+}$must transfer from the epithelial cell network into the connective tissue gap junction network, which comprises otic fibrocytes in the spiral ligament coupled to basal cells and intermediate cells in stria vascularis (Kikuchi et al. 2000; Liu and Zhao 2008; Zhao et al. 2006). The molecular basis of the mechanism mediating $\mathrm{K}^{+}$transfer between the two networks remains undefined (Hibino and Kurachi 2006; Kikuchi et al. 2000; Kikuchi et al. 1995; Mistrik et al. 2009; Spicer and Schulte 1996; Wangemann 2006; Zhao et al. 2006).

The chief cellular candidates for mediating the $\mathrm{K}^{+}$ secretion from the epithelial syncytium are "root cells" (Kimura 1984; Spicer and Schulte 1996). Their cell bodies lie within the outer sulcus (Fig. 1) often underlying Claudius cells (Kimura 1984). The rootlike processes project into the spiral ligament in close association with capillaries and type 2 fibrocytes (Galic and Giebel 1989; Spicer and Schulte 1996). There are no reports of gap junctions or cellular connections between root cells and spiral ligament fibrocytes (Hibino and Kurachi 2006). Root cell processes display various specializations that suggest the cells carry out secretion or absorption of fluids and/or ions (Kimura 1984).

In this study, we characterize the biophysical properties of root cells, to investigate the nature of their hypothetical $\mathrm{K}^{+}$secretion. We find that root cells are extensively coupled via dye-permeable gap junctions, and that uncoupled cells have a high resting conductance. This conductance is dominated by $\mathrm{Ba}^{2+}$ sensitive, weakly rectifying channels. The $\mathrm{K}^{+}$channel subunit Kir4.1 is expressed by root cells, and is localized at the root cell process membrane. These findings suggest that the membrane properties of root cells are consistent with roles in cochlear $\mathrm{K}^{+}$recirculation and spatial buffering.

\section{MATERIAL AND METHODS}

\section{Animals}

Young pigmented guinea pigs $(150-250 \mathrm{~g})$ were killed by $\mathrm{CO}_{2}$ inhalation, in accordance with the United Kingdom Animals (Scientific Procedures) Act of 1986.

\section{Fixed vibratome slices}

Bullae tympanicae were removed and the otic capsule exposed. A small hole was made in the apex of the otic capsule, and the whole cochlea was perfused with $4 \%$ paraformaldehyde (PFA) in phosphate-buffered saline (PBS). Cochleae were fixed in PFA for $30 \mathrm{~min}$ at room temperature and then washed several times in PBS. For whole cochlear slices, bullae were decalcified in $4 \%$ EDTA for $48 \mathrm{~h}$ at $4^{\circ} \mathrm{C}$, the otic capsules dissected from the bullae and then decalcified for a further $24 \mathrm{~h}$. Whole otic capsules or dissected lateral walls were suspended in low gelling temperature agarose (type VII, Sigma), and mounted on a vibratome block and sectioned at $200 \mu \mathrm{m}$. Differential interference contrast micrographs were taken using a digital camera mounted on an upright microscope (Axioplan 2 Imaging; Carl Zeiss MicroImaging, Germany).

\section{Confocal immunofluorescence}

Fixed vibratome slices were permeabilized and blocked (0.1\% Triton-X 100 with $10 \%$ normal goat serum in PBS) for $30 \mathrm{~min}$ at room temperature, and then incubated in primary antibodies overnight at $4^{\circ}$ C. The mouse monoclonal anti-acetylated tubulin antibody (Sigma) was used at 1:1,000. The mouse monoclonal anti-Cx26 antibody (Zymed, San Francisco, CA, USA) was used at 1:400. The rabbit polyclonal anti-Kir4.1 antibody (Alomone Labs, Israel) was used at 1:400. The mouse monoclonal anti-Na,K-ATPase $\alpha 1$ subunit antibody (Sigma) was used at 1:1,000. In controls primary antibodies were omitted. Following several PBS washes, slices were incubated in Alexa-Fluor tagged secondary antibodies (Invitrogen, UK) in the dark for $60 \mathrm{~min}$ at room temperature. Slides were cover-slipped and mounted using Vectashield with 4',6-diamidino-2-phenylindole (DAPI; Vector Labs, UK). Imaging was carried out using a laser scanning confocal microscope (LSM510; Carl Zeiss MicroImaging, Germany) as described elsewhere (Jagger and Forge 2006). Micrographs were converted to TIFF format, and adjusted for optimal contrast and brightness.

\section{Whole-cell recordings and dye injection}

Dissection was performed in cold artificial perilymph (in mM: $140 \mathrm{NaCl}, 4 \mathrm{KCl}, 1 \mathrm{MgCl}_{2}, 1.3 \mathrm{CaCl}_{2}, 10$ HEPES, and 5 glucose; $\mathrm{pH}$ adjusted to 7.3 with $\mathrm{NaOH}$ ). All chemicals were obtained from Sigma unless stated. Individual turns of dissected lateral wall were mounted in agarose (as above) and sectioned at $200 \mu \mathrm{m}$. Slices were stored in artificial perilymph on ice until used. Slices were placed in a recording chamber (volume $400 \mu \mathrm{l})$ mounted on an upright microscope (E600FN, Nikon, Japan) and were superfused with artificial perilymph $(1 \mathrm{ml} / \mathrm{min})$. Slices were held beneath short lengths of platinum wire to prevent movement. Experiments were conducted at room temperature $\left(20-24^{\circ} \mathrm{C}\right)$. Patch clamp recordings were performed under infrared differential interference contrast (IR-DIC) video-microscopy, using a CCD video camera and IR-DIC optics 
mounted on the microscope. Before recordings, overlying Claudius cells could be removed using a suction pipette. Dyes were injected into root cell bodies during 10-min whole-cell patch clamp recordings. Recordings were performed using a patch clamp amplifier (Axopatch 200B; Axon Instruments, Foster City, CA, USA) and a Digidata board (Axon Instruments) under the control of computer software (pClamp version 8; Axon Instruments). Patch pipettes were fabricated on a vertical puller (Narishige, Japan) from capillary glass (GC120TF-10; Harvard Apparatus, UK).

Pipettes were filled with a KCl-based solution (in $\mathrm{mM}$ : $140 \mathrm{KCl}, 10 \mathrm{NaCl}, 2 \mathrm{MgCl}_{2}$, 5 HEPES, 0.5 EGTA, 3 $\mathrm{Na}_{2} \mathrm{ATP}$, and 5 glucose; $\mathrm{pH}$ adjusted to 7.3 with $\mathrm{KOH}$ ). This solution was supplemented with $0.2 \%$ neurobiotin (molecular weight, $287 \mathrm{Da}$; charge, +1 ; Vector Labs) and $0.2 \%$ fluorescein dextran (10 kDa; anionic; Invitrogen) or $0.2 \%$ Lucifer yellow (di-lithium salt; $443 \mathrm{Da}$; charge, -2 ; Sigma). Pipette solutions were filtered at $0.2 \mu \mathrm{m}$ and centrifuged to remove small insoluble particles. Pipettes had an access resistance of 2-3 $\mathrm{M} \Omega$, measured in artificial perilymph. In recordings from uncoupled cells, voltage errors due to series resistance were compensated at $70 \%$ online. Current-voltage $(I-V)$ relationships were constructed by measuring the steady-state current $10 \mathrm{~ms}$ before the end of voltage steps. All data were corrected offline for a calculated liquid junction potential of $-4 \mathrm{mV}$. Group data is presented as mean \pm standard deviation, statistical analysis was performed using Prism version 4.03 for Windows (GraphPad Software, San Diego CA, USA). At the termination of recordings, slices were fixed immediately in $4 \%$ PFA for $20 \mathrm{~min}$ at room temperature. Following fixation, slices were prepared for immunofluorescence as described above. To counter-stain gap junction plaques, some slices were incubated overnight at $4^{\circ} \mathrm{C}$ in the mouse antiCx26 antibody, and then in anti-mouse secondary antibody as described. To visualize neurobiotin, Alexa555-Fluor tagged streptavidin (1;1,000; Invitrogen) was added with the anti-mouse secondary antibody. Slides were cover-slipped using Vectashield with DAPI (Vector Labs). Confocal imaging was carried out as described above.

\section{Immunogold electron microscopy}

Tissues were fixed in situ by direct perfusion of the cochleae with $4 \%$ paraformaldehyde and $0.025 \%$ glutaraldehyde in PBS for $2 \mathrm{~h}$ at room temperature. The cochleae were then dissected. The lateral wall tissues were dehydrated in an ethanol series and then infiltrated with LRWhite plastic. The plastic was polymerized by $\mathrm{U} / \mathrm{V}$ light at $-30^{\circ} \mathrm{C}$. Thin sections for transmission electron microscopy (TEM) were mounted on nickel grids and floated on a blocking solution (10\% horse serum, $100 \mathrm{mM}$ l-lysine in PBS with 0.15\% Tween, $\mathrm{pH}$
8.2) for $30 \mathrm{~min}$. The sections were washed in several changes of PBS- $0.15 \%$ Tween, $\mathrm{pH}$ 8.2, before overnight incubation at $4^{\circ} \mathrm{C}$ in the anti-Kir4.1 primary antibody diluted 1:50 in PBS-Tween. After labeling with the primary antibody, the sections were washed several times in PBS-Tween and then incubated for $1 \mathrm{~h}$ at room temperature with a 1:50 dilution of an anti-rabbit secondary antibody, conjugated to 10-nm gold particles. They were rinsed in PBS and exposed briefly to $0.01 \%$ glutaraldehyde, then rinsed in distilled water and allowed to dry. The sections were lightly counterstained with uranyl acetate and lead citrate. TEM micrographs were obtained using a Jeol 1200 EXII microscope operating at $80 \mathrm{kV}$. Images were collected using a digital camera (Gatan Ultrascan 1000).

\section{RESULTS}

Root cells can be identified in a cochlear lateral wall preparation

Cochlear root cells lie at the lateral edge of the epithelial gap junction network (Fig. 1A). Their cell bodies are located within the cochlear outer sulcus (Fig. 1B), and are found underlying the Claudius cells in the basal cochlear turns (Kimura 1984). The nuclei of root cells reside in the cell body or within the root process. The microtubule-rich root processes extend into the spiral ligament (Fig. 1C). In order to determine the electrophysiological properties of root cells, we devised a cochlear lateral wall slice preparation (Fig. 2A), in which the root cell bodies were exposed and thus accessible for whole-cell patch clamp recordings. During whole-cell recordings, dyes were injected into the root cell body via the patch pipette, and on careful retraction of the pipette from the cell membrane, the dyes were trapped within the cell cytoplasm. Following the majority of recordings (24/37), injected Lucifer yellow could be detected in several root cell bodies, and also in their processes (Fig. 2B). Fluorescein dextran, which is too large to permeate gap junctions (molecular weight $10 \mathrm{kDa}$ ), was detected in single cells only (Fig. 2C; $n=4$ ). Whole-cell patch clamp recordings demonstrated large voltage-activated currents (Fig. 2D), and that the root cell syncytium could be uncoupled using bath application of $2 \mathrm{mM}$ 1-octanol (Fig. 2E). The octanol-sensitive current showed little voltage dependence (Fig. 2F).

Dye transfer reveals intercellular coupling and tonotopic variations of root cell process morphologies

The morphologies of root cell processes extending into the spiral ligament were examined further by the 


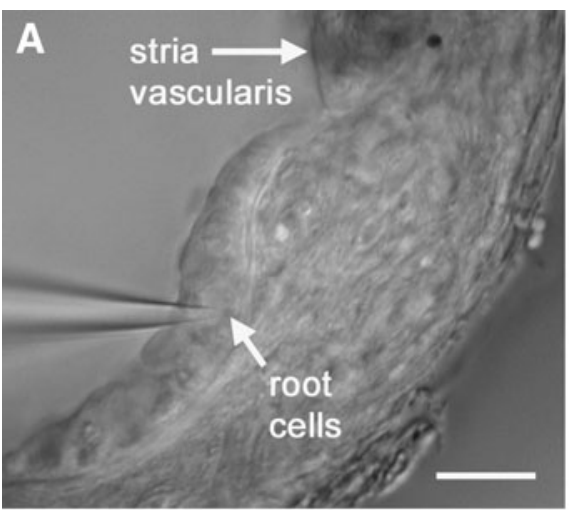

D

control

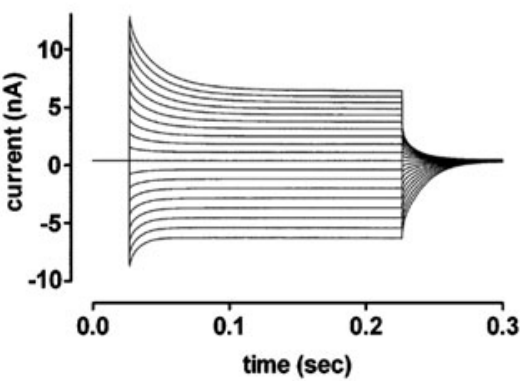

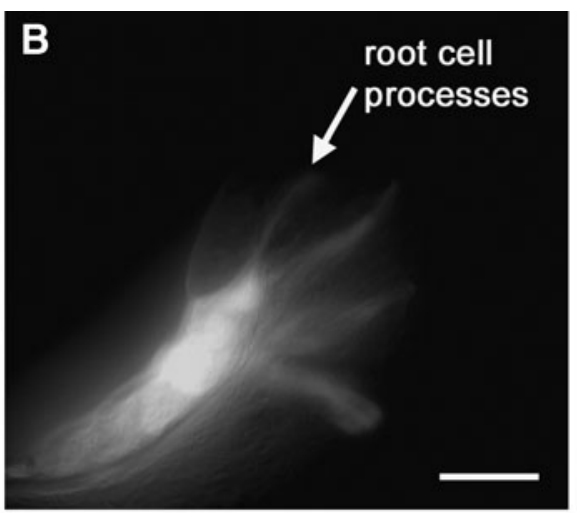

E

+ octanol

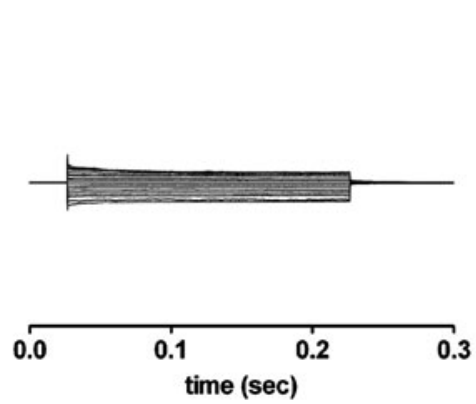



$\mathbf{F}$

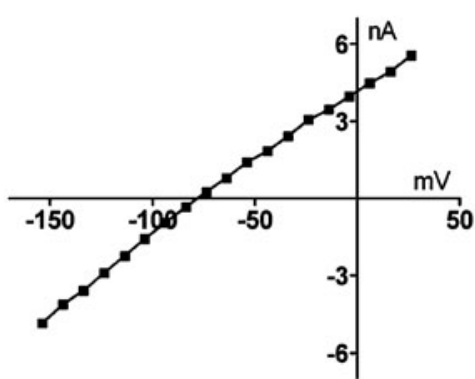

FIG. 2. Identification of intercellular coupling between root cells within a slice preparation of the guinea pig cochlear lateral wall. A An infrared differential interference contrast video-micrograph of a lateral wall slice preparation captured during a whole-cell patch clamp recording. Root cell bodies could be identified within the outer sulcus. Claudius cells were aspirated from this slice before commencement of the recording. B Video-micrograph captured following the recording shown in $\mathbf{A}$, showing Lucifer yellow epifluorescence within several root cell bodies, and within their

confocal imaging of neurobiotin (Fig. 3), which was co-injected during the whole-cell recordings described above. Neurobiotin/streptavidin fluorescence resists laser bleaching, and allows detailed imaging of gap junction coupled cells (Jagger and Forge 2006). Numerous neurobiotin-filled root cell processes could be detected within the spiral ligament (Fig. 3A), interdigitating between otic fibrocytes. There was extensive dye coupling between the cells in the longitudinal direction (i.e., along the cochlear partition; Fig. 3B). It has been reported that the morphology of individual root processes is dependent upon their location along the cochlear partition (Galic and Giebel 1989; Kimura 1984; Spicer and Schulte 1996). Consequently, root processes were examined in slice preparations dissected from different tonotopic locations within the cochlea. Slices were taken from turn 2, a region of the guinea pig cochlea that codes for acoustic frequencies between $2-6 \mathrm{kHz}$, and from turn 4 , the region that codes for $0.3-0.6 \mathrm{kHz}$ (Pujol et al. 1992). In turn 2 there were several morphologically distinct root cell sub-types (Fig. 3C). Thin and unbranched root cell processes projected from cells in

processes invading the spiral ligament. C Bright-field video-micrograph captured following a different recording, showing Fluorescein dextran epi-fluorescence within a single root cell. Scale bars $\mathbf{A}-\mathbf{C}=$ $20 \mu \mathrm{m}$. D Whole-cell recording from coupled root cells in a lateral wall slice (step potentials $-154 \mathrm{mV}$ to $+26 \mathrm{mV},-74 \mathrm{mV}$ holding potential), showing large inward and outward voltage-activated currents. E Following the bath application of $2 \mathrm{mM} 1$-octanol the inward and outward currents were attenuated. F Current-voltage relationship of the digitally subtracted octanol-sensitive current.

the upper region of the outer sulcus, into the region of the spiral prominence where type 2a fibrocytes reside (Spicer and Schulte 1996). From cells in the middle region of the outer sulcus, root cell processes projected to type $2 \mathrm{~b}$ fibrocytes. These processes appeared thicker, and often displayed terminal branching. Root cell processes extending from the lower region of the outer sulcus were thick and bifurcated, and projected towards type 2c fibrocytes. In turn 4 the root cell processes were fewer in number, and consisted of less distinct morphological sub-types (Fig. 3D), confirming previous observations (Galic and Giebel 1989; Kimura 1984; Spicer and Schulte 1996). In dye injection reconstructions from turn 4, there were no root cell processes that projected towards type 2c fibrocytes.

Barium-sensitive weakly rectifying currents are the predominant resting conductance of uncoupled root cells

Preliminary patch clamp recordings demonstrated that root cell syncytia could be uncoupled using bath 

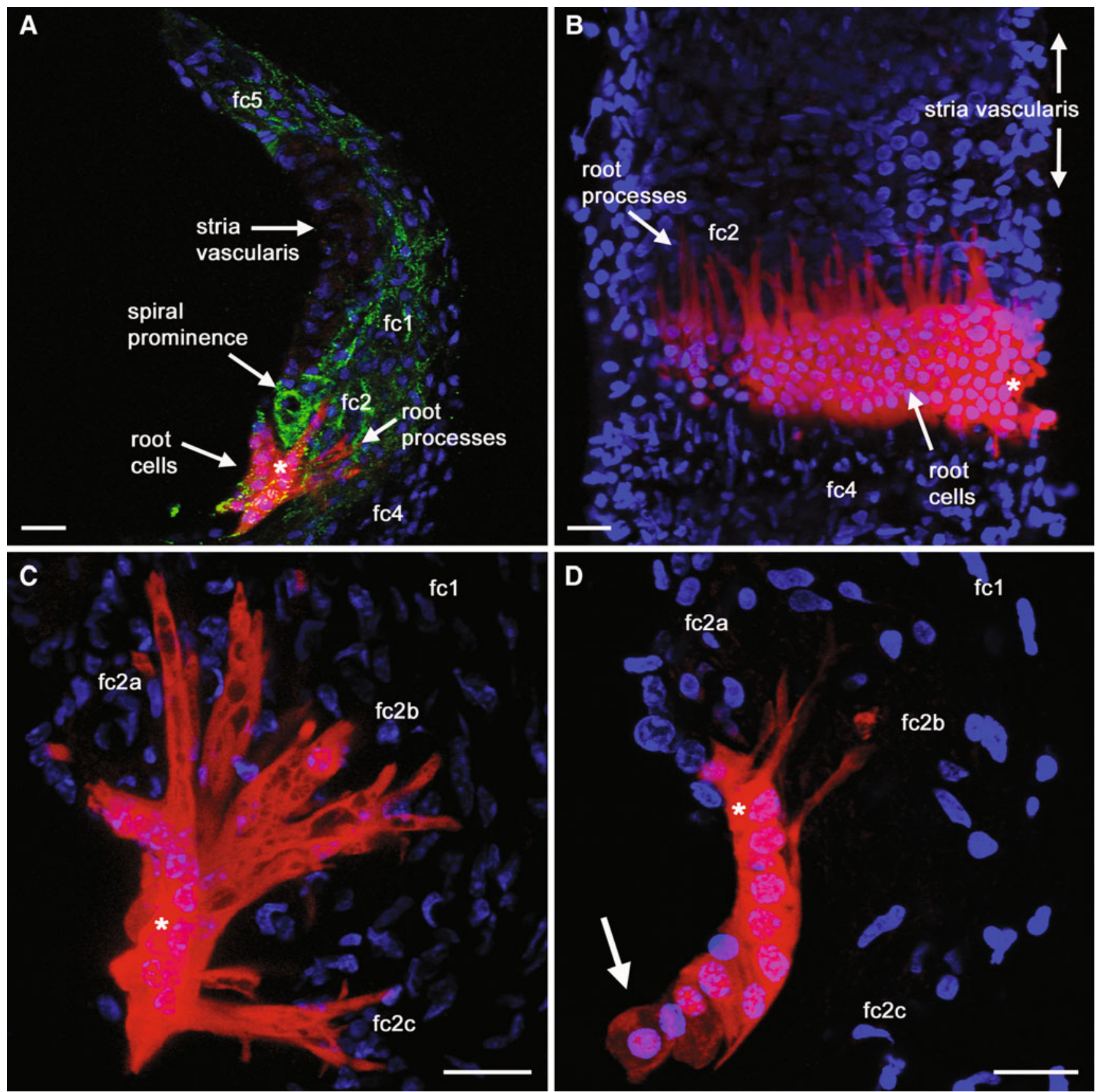

FIG. 3. Post-fixation analysis of intercellular dye transfer reveals the complex morphology of root cells. A-D show projections of confocal image stacks, demonstrating intercellular neurobiotin transfer within cochlear lateral wall preparations. A Injected neurobiotin (red) in turn 2 coupled root cells within a radial slice. The locations of the major sub-types of otic fibrocytes (fc1-5) are identified. The slice was counterstained with an anti-Cx26 antibody (green), to label gap junctions. Nuclei were stained with DAPI (b/ue). B Longitudinal neurobiotin spread between root cells throughout the depth of a turn 2 lateral wall slice. The slice was removed from the suspending agarose, and oriented to be viewed as though from scala media. The individual neurobiotin-filled root cell processes could be seen invading the spiral ligament, inter-digitating between type 2 fibrocytes. C In a turn 2 slice preparation, neurobiotin staining within a $20-\mu \mathrm{m}$ stack projection delineated distinct sub-types of root cell

processes. From the upper region of the outer sulcus, fine unbranched root cell processes projected between type 2a fibrocytes within the spiral prominence. From the middle region of the outer sulcus, wider diameter and branched processes projected between type $2 \mathrm{~b}$ fibrocytes behind the spiral prominence. From the lower region of the outer sulcus, shorter bifurcating processes extended laterally between type 2c fibrocytes. D In a slice preparation of turn 4 , neurobiotin staining within a $20-\mu \mathrm{m}$ stack projection revealed fewer and smaller root cell processes. There were a few processes projecting from cells in the upper region of the outer sulcus, and a few processes projecting from cells in the middle region of the outer sulcus. There were no discernible processes from the lower region. Neurobiotin was detected in putative Claudius cells attached to the outer sulcus (arrow). Asterisks denote injected cells. Scale bars= $20 \mu \mathrm{m}$. 
application of 1-octanol (Fig. 2D-F). In subsequent experiments to characterize the membrane currents of individual root cells, slices were pre-incubated briefly in $2 \mathrm{mM}$ 1-octanol. Figure 4 shows representative current traces from neurobiotin-filled octanol-uncoupled root cells in turn 2. Root cells located in the upper region of the outer sulcus had processes projecting towards type 2a fibrocytes (Fig. 4Ai), and had weakly rectifying
$\mathrm{Ai}$

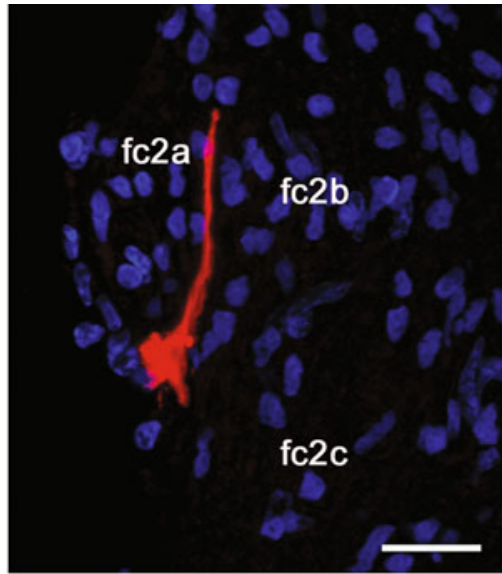

$\mathrm{Bi}$

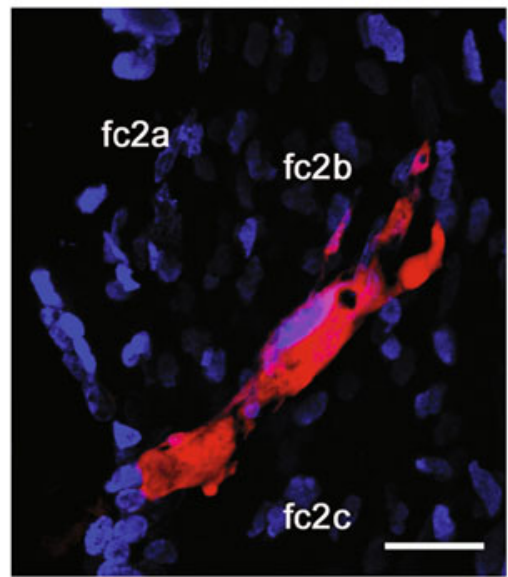

Ci

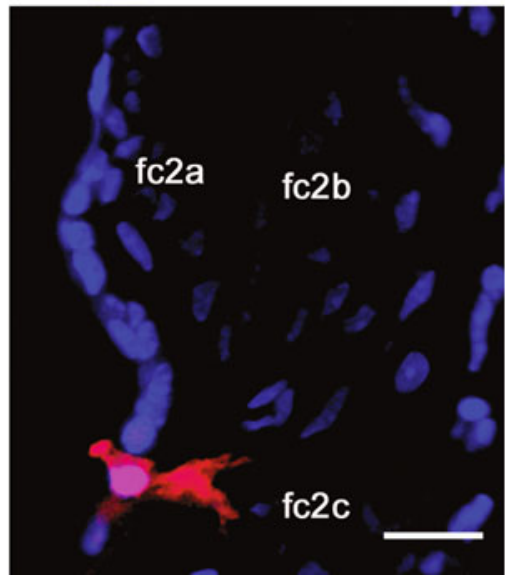

Aii

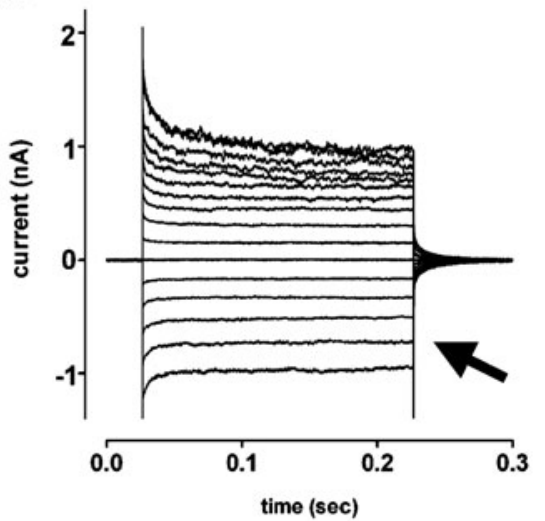

Bii

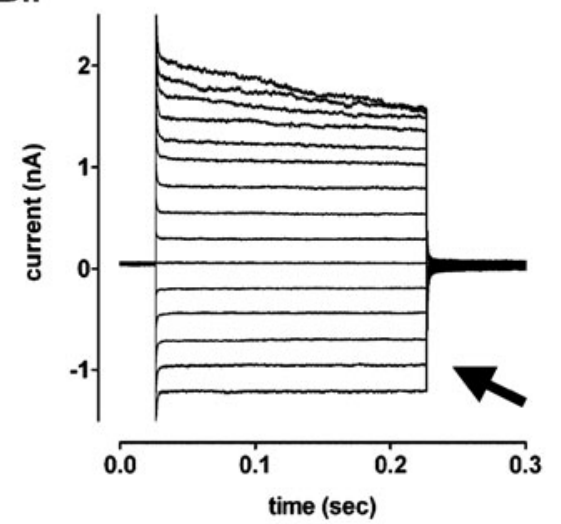

$\mathrm{Cii}$

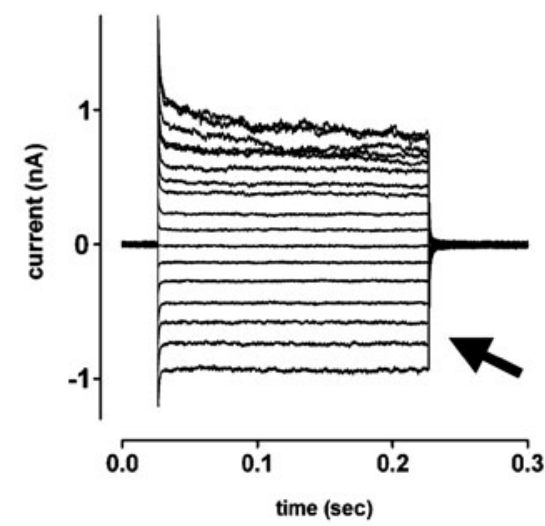

Aiii

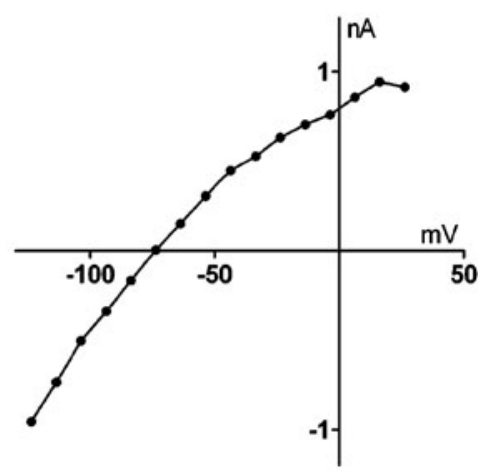

Biii

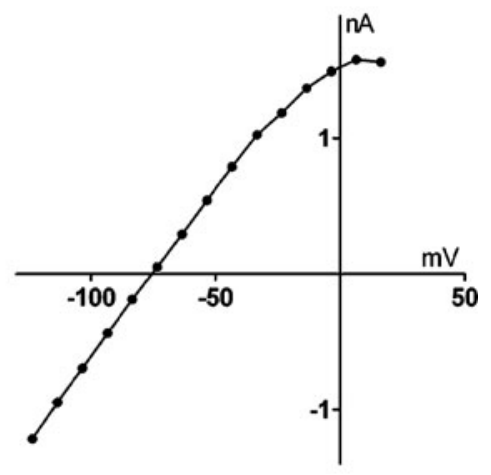

Ciii

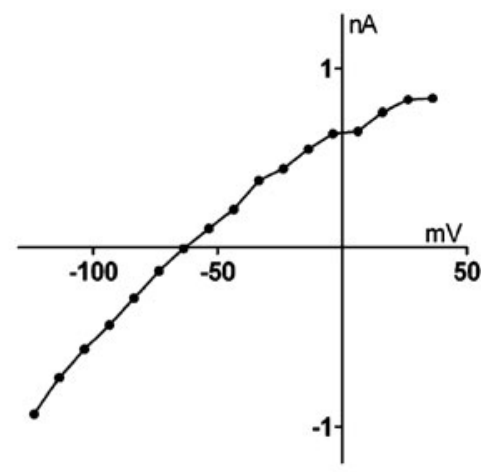

FIG. 4. Whole-cell currents recorded from uncoupled turn 2 root cells. A-C show representative data from root cells in lateral wall slices pre-incubated with $2 \mathrm{mM}$ 1-octanol. Ai Neurobiotin labeling (red) revealed a single root cell possessing a process extending between the type 2a fibrocytes $\left(f_{c} 2 a\right)$ of the spiral prominence. Nuclei were stained with DAPI (b/ue). Aii The root cell displayed weakly rectifying whole-cell currents in response to voltage steps $(-124 \mathrm{mV}$ to $+26 \mathrm{mV},-74 \mathrm{mV}$ holding potential). Aiii Currentvoltage $(I-V)$ relationship for traces shown in Aii. Bi Neurobiotin labeling of a root cell with a process extending between the type $2 b$ fibrocytes $\left(f_{c} 2 b\right)$. Bii The root cell displayed weakly rectifying currents $(-124 \mathrm{mV}$ to $+16 \mathrm{mV},-74 \mathrm{mV}$ holding potential). Biii $I-V$ relationship for traces shown in Bii. Ci Neurobiotin labeling of a root cell with a bifurcating process extending towards type 2c fibrocytes $\left(f_{C} 2 c\right)$. Cii This root cell also displayed weakly rectifying currents $(-124 \mathrm{mV}$ to $+36 \mathrm{mV},-64 \mathrm{mV}$ holding potential). Ciii $I-V$ relationship for traces shown in Cii. The arrows in Aii, Bii, and Cii denote the comparable inward currents at hyperpolarized potentials in the three cells. Scale bars $=20 \mu \mathrm{m}$. 
membrane currents (Fig. 4Aii-Aiii). Comparable currents were seen in root cells in the middle region of the outer sulcus projecting towards type $2 \mathrm{~b}$ fibrocytes (Fig. 4Bi-Biii), and in root cells in the lower region of the outer sulcus projecting towards type 2c fibrocytes (Fig. 4Ci-Ciii). Analysis of the resting conductance of these morphologically distinct cell types did not reveal statistically significant differences (not shown). Consequently the cells from turn 2 were grouped for subsequent comparisons with cells from turn 4 (Fig. 6).

The weakly rectifying currents in turn 2 root cells were attenuated by bath applied $1 \mathrm{mM} \mathrm{Ba}^{2+}$ (Fig. 5A and $\mathrm{B}$ ), a blocker of currents carried by the $\mathrm{K}^{+}$ channel subunit Kir4.1 in glia (Connors and Kofuji 2002; Neusch et al. 2006; Neusch et al. 2001). Application of $\mathrm{Ba}^{2+}$ also caused depolarization of root cells (Fig. 5B and $\mathrm{C}$ ). The mean $V_{\mathrm{z}}$ of root cells $(-66.7$ $\pm 8.7 \mathrm{mV}, n=6)$ was significantly decreased following the application of $\mathrm{Ba}^{2+}(-38.0 \pm 6.2 \mathrm{mV} ; n=6 ; P=$ 0.0003 , Student's paired $t$ test). Individual root cells from turn 4 also had weakly rectifying currents (Fig. 6A). However, inward currents measured from $I-V$ relationships at $-120 \mathrm{mV}$ in turn 2 cells $(-1,090 \pm$ $343 \mathrm{pA}, n=9$ ) were significantly larger than those in turn 4 cells $(-268 \pm 153 \mathrm{pA} ; n=6 ; P=0.0001$, Student's unpaired $t$ test). The estimated membrane capacitance of turn 2 root cells was significantly larger than that of turn 4 cells (Fig. 6B), reflecting their apparent larger surface area. The current density $(\mathrm{pA} / \mathrm{pF}$, measured at $-120 \mathrm{mV}$ ) was significantly higher in turn 2 cells compared to turn 4 cells (Fig. 6C), suggest- ing that channel density was higher in cells from the basal cochlear region. The mean $V_{\mathrm{z}}$ of turn 2 cells was hyperpolarized compared to that of turn 4 cells (Fig. 6D). Together these data suggest that in addition to differences in root cell morphology between highand low-frequency cochlear regions, there are also differences in their specific biophysical properties.

The Kir4.1 channel subunit is localized in the root cell process membrane

Our voltage clamp recordings suggested that root cells express $\mathrm{Ba}^{2+}$-sensitive weakly rectifying $\mathrm{K}^{+}$channels. Kir4.1 channel subunits, which conduct weakly inwardly rectifying currents in glia (Connors and Kofuji 2002; Kofuji and Newman 2004; Neusch et al. 2006; Neusch et al. 2001), have been suggested to play homeostatic roles within cochlear tissues (Hibino et al. 1999; Hibino et al. 1997; Marcus et al. 2002; Rozengurt et al. 2003; Takeuchi et al. 2000). Consequently, we re-investigated the expression of Kir4.1 in the guinea pig cochlear lateral wall. Firstly, using a rabbit polyclonal anti-Kir4.1 antibody, we carried out confocal immunofluorescence experiments on vibratome lateral wall slices (Fig. 7). As might be expected from previous studies of cochlear tissues, in turn 2 there was abundant expression of Kir4.1 in intermediate cells of stria vascularis (Fig. 7Ai). Kir4.1 immunofluorescence was also detected in root cell bodies, and in their processes projecting to type 2 fibrocytes in the spiral ligament. As shown previously (Spicer and Schulte 1991), type 2 fibrocytes enveloping
A

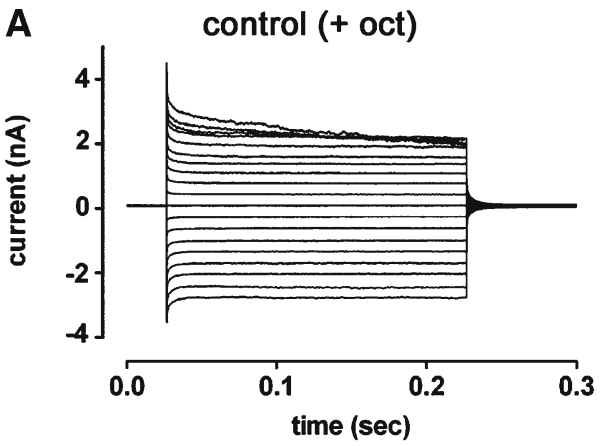

B



$+\mathrm{Ba}^{2+}$



C

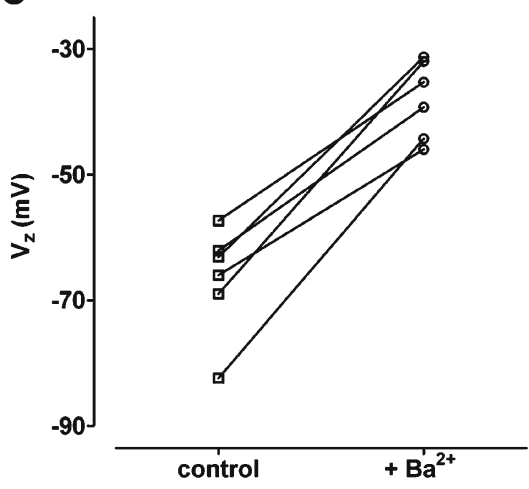

FIG. 5. Weakly rectifying currents in turn 2 root cells were blocked by $\mathrm{Ba}^{2+}$. A Following bath application of $2 \mathrm{mM} 1$ octanol (control $(+o c t))$, a root cell displayed weakly rectifying whole-cell currents in response to voltage steps $(-154 \mathrm{mV}$ to $+26 \mathrm{mV},-74 \mathrm{mV}$ holding potential). The currents were attenuated by subsequent bath application of $1 \mathrm{mM}$ $\mathrm{Ba}^{2+}$. B Current-voltage $(I-V)$ relationships for traces shown in A. C Data for six individual root cells, showing changes of zero-current potential $\left(V_{\mathrm{z}}\right.$, measured from $I-V$ relationships) following bath application of $1 \mathrm{mM} \mathrm{Ba}^{2+}$. 


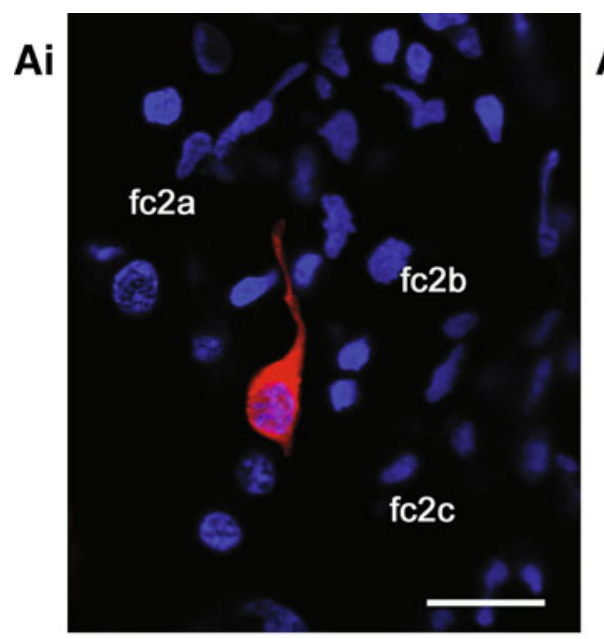

Aii



C



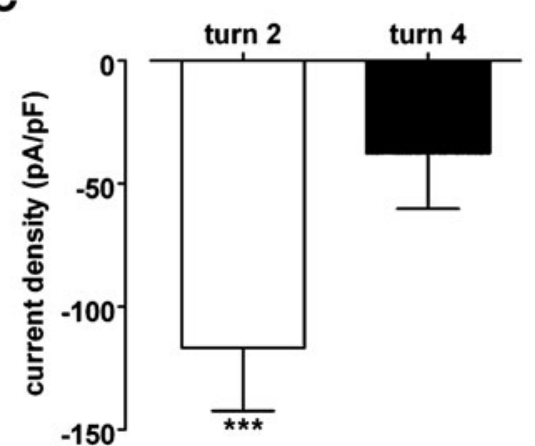

Aiii

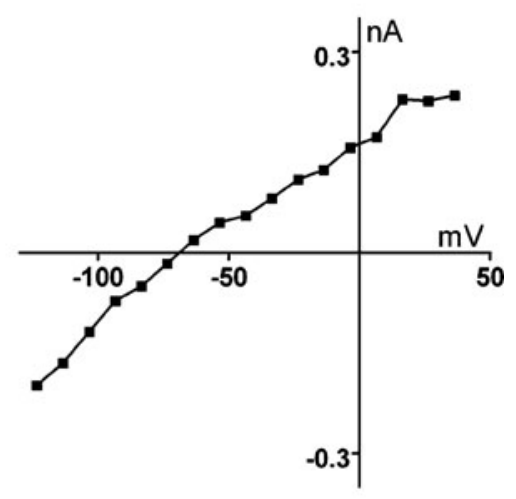

D

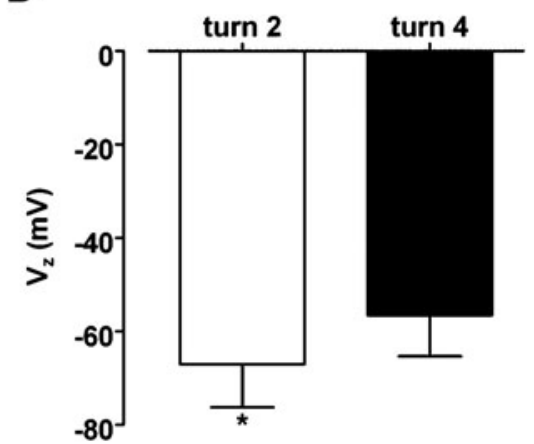

FIG. 6. Weakly rectifying currents in turn 4 root cells are smaller than those in turn 2 root cells. Ai In a turn 4 lateral wall slice preincubated with $2 \mathrm{mM}$ 1-octanol, neurobiotin labeling (red) revealed a single root cell possessing a process extending between the type $2 \mathrm{a}$ fibrocytes $\left(f_{c} 2 a\right)$ of the spiral prominence. Nuclei were stained with DAPI (blue). Scale bar=20 $\mu \mathrm{m}$. Aii The root cell displayed small weakly rectifying whole-cell currents in response to voltage steps

the root cell processes expressed Na,K-ATPase (Fig. 7Aii). Kir4.1 immunofluorescence was also detected in the root cells of turn 4 lateral wall slices (Fig. 7B), though it was less readily detected in stria vascularis in this region compared to turn 2. To determine the sub-cellular localization of Kir4.1, the polyclonal Kir4.1 antibody was used for immunogold labeling of thin sections of guinea pig lateral wall. Root cells and their inter-digitated bundles could be identified in the region of the outer sulcus and spiral ligament (Fig. 8A), their cytoplasm being characteristically rich in ribosomes, elongated mitochondria, and tubular fibrils (Kimura 1984). Gold particles labeled the membrane of root cell processes (Fig. 8B and C), closely associated with the membranes of adjacent fibrocytes. The specificity of the anti-Kir4.1 labeling was confirmed within strial intermediate cells (Fig. 8D). The density of gold particles was higher in intermediate cells compared to root cells, likely reflecting the larger weakly rectifying currents in intermediate cells observed by others (see above). From these experiments we conclude that the localization of Kir4.1 subunits is consistent with them
$(-124 \mathrm{mV}$ to $+36 \mathrm{mV},-64 \mathrm{mV}$ holding potential). Aiii Currentvoltage $(I-V)$ relationship for traces shown in Aii. B Membrane capacitance $\left(C_{\mathrm{m}}\right)$ measurements for root cells from turn $2(n=9)$ and turn 4 ( $n=6 ; P=0.0004)$. C Current density $(\mathrm{pA} / \mathrm{pF})$ measurements for the cells in $\mathbf{B}(P<0.0001)$. Inward current at $-120 \mathrm{mV}$ was measured from $I-V$ relationships, and divided by membrane capacitance. $\mathbf{D} V_{\mathrm{z}}$ measurements for these cells $(P=0.0466)$.

playing a role in the secretion of $\mathrm{K}^{+}$from root cell processes into the spiral ligament, and completing cochlear $\mathrm{K}^{+}$recirculation.

\section{DISCUSSION}

Little doubt remains that normal auditory transduction relies on the continuous maintenance of a low perilymphatic $\left[\mathrm{K}^{+}\right]$and a high endolymphatic $\left[\mathrm{K}^{+}\right]$. This maintenance ensures the longevity of sensory hair cells and the generation of the endocochlear potential. The ion transporting mechanisms that regulate these concentrations have been characterized in a number of cochlear tissues, leading to widely held hypotheses of $\mathrm{K}^{+}$"recirculation" and "spatial buffering" (Forge et al. 2003a; Hibino and Kurachi 2006; Kikuchi et al. 2000; Kikuchi et al. 1995; Nickel and Forge 2008; Nin et al. 2008; Spicer and Schulte 1996; Takeuchi et al. 2000; Wangemann 2006; Weber et al. 2001; Zhao et al. 2006). In common with these mechanisms studied in the CNS and retina (Kofuji 


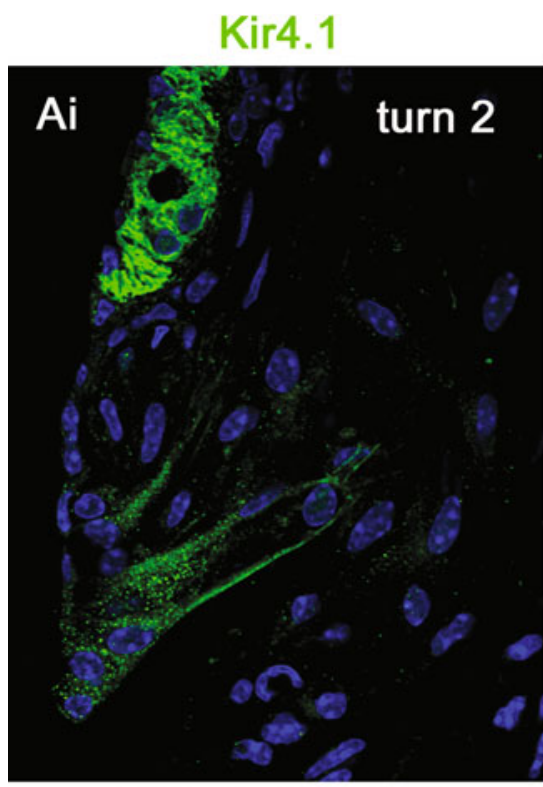

Kir4.1 Na,K-ATPase
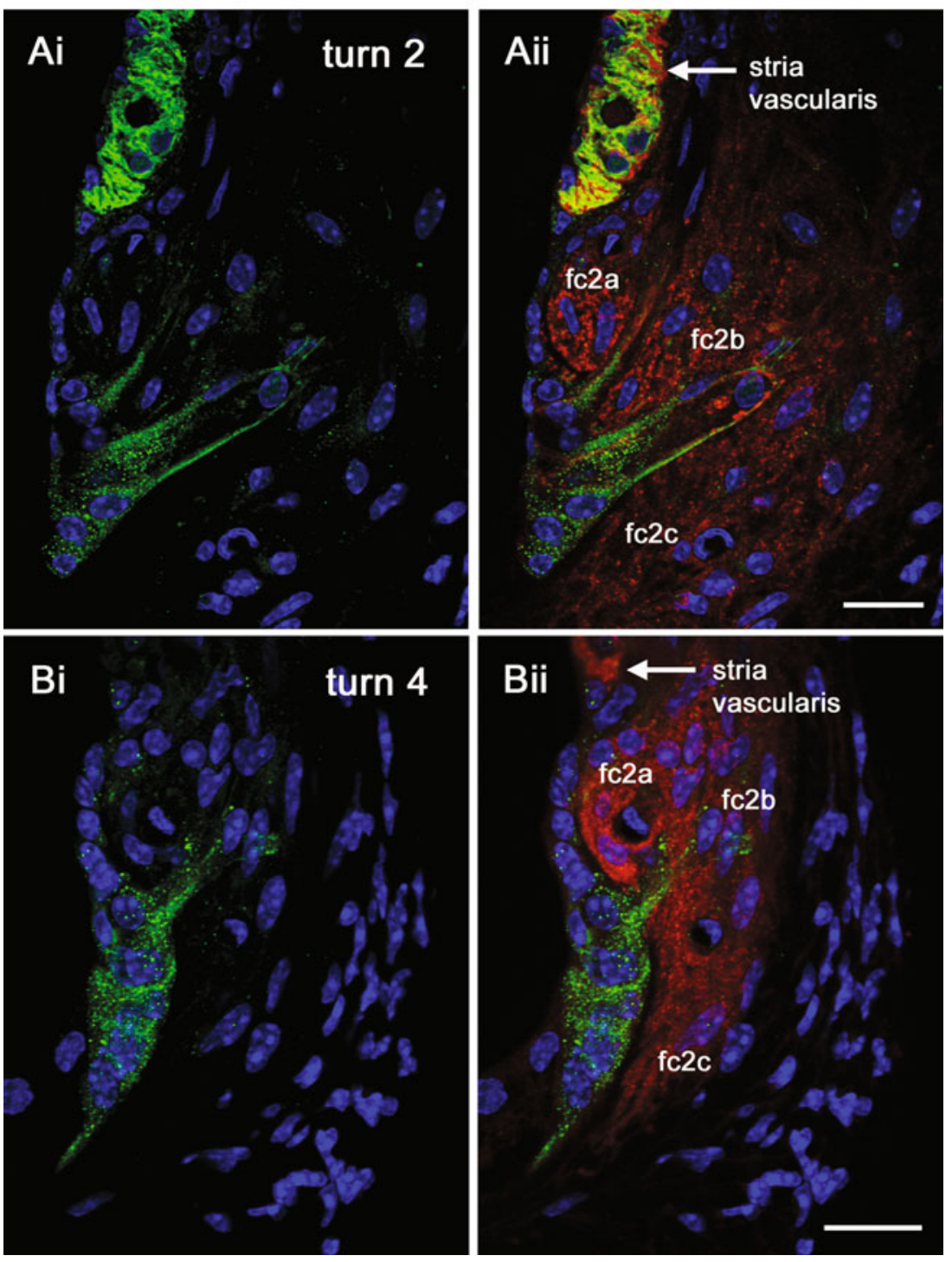

FIG. 7. Kir4.1 immunofluorescence in lateral wall slices. A-B show single confocal images from cochlear lateral wall slices labeled with an antibody directed against Kir4.1 (green) and an antibody against $\mathrm{Na}, \mathrm{K}-\mathrm{ATP}$ ase $\alpha 1$ subunit (red). Nuclei were stained with DAPI (blue). Ai In a turn 2 slice Kir4.1 immunofluorescence was detected in root cell bodies and their processes, and more strongly within intermediate cells of stria vascularis. Aii Na,K-ATPase immunofluorescence revealed the relationship of the Kir4.1-labeled root cell processes with the $\mathrm{Na}, \mathrm{K}-\mathrm{ATP}$ ase-labeled type 2 fibrocytes $\left(f_{C} 2 a-c\right)$. Bi In an upper turn 4 slice, Kir4.1 immunofluorescence was detected in root cell bodies and their processes, though these were fewer in number than in turn 2. Bii Kir4.1-labeled root cell processes were in close apposition with Na,K-ATPase-labeled type 2 fibrocytes. Abbreviations: $f_{c} 2 a$ type 2 a fibrocytes, $f_{c} 2 b$ type $2 b$ fibrocytes, $f_{c} 2 c$ type $2 c$ fibrocytes. Scale bars $=20 \mu \mathrm{m}$. and Newman 2004), cochlear $\mathrm{K}^{+}$recirculation and spatial buffering both rely on gap junctional coupling throughout the epithelial cell network, and the ability of cells at the edges of the network to secrete $\mathrm{K}^{+}$. Thus, we studied the electrophysiological properties of root cells, in a slice preparation of the guinea pig cochlear lateral wall. Dye transfer experiments revealed that root cells were coupled via gap junctions that were permeable to both Lucifer yellow and neurobiotin. Dye transfer also enabled morphological description of the root cell processes penetrating the spiral ligament. Neurobiotin, a molecule that permeates gap junctions constructed from known cochlear connexins (Jagger and Forge 2006), did not enter spiral ligament fibrocytes. This confirmed the lack of cytoplasmic connection between the root cell processes and fibrocytes (Hibino and Kurachi 2006). In octanol-uncoupled cells, we found $\mathrm{Ba}^{2+}$-sensitive weakly rectifying currents. Kir4.1 subunits, whose biophysical properties are consistent with those we observed, were expressed at the membrane of root cell processes, and so we suggest that Kir4.1 mediates the resting conductance of individual root cells. Although the membrane expression of $\mathrm{K}^{+}$channel subunits does not confirm resting efflux, the data indicate that the membrane properties of root cells are consistent with them playing a pivotal role in the recirculation and spatial buffering of $\mathrm{K}^{+}$.

Root cells form the lateral limits of the epithelial gap junction network

Following hair cell transduction, the resting perilymphatic $\left[\mathrm{K}^{+}\right]$is raised locally by as much as $3 \mathrm{mM}$ (Johnstone et al. 1989). The underlying Deiters' cells provide an essential homeostatic function by "siphoning” excess $\mathrm{K}^{+}$, preventing prolonged depolarization of the hair cell membrane potential (Boettger et al. 


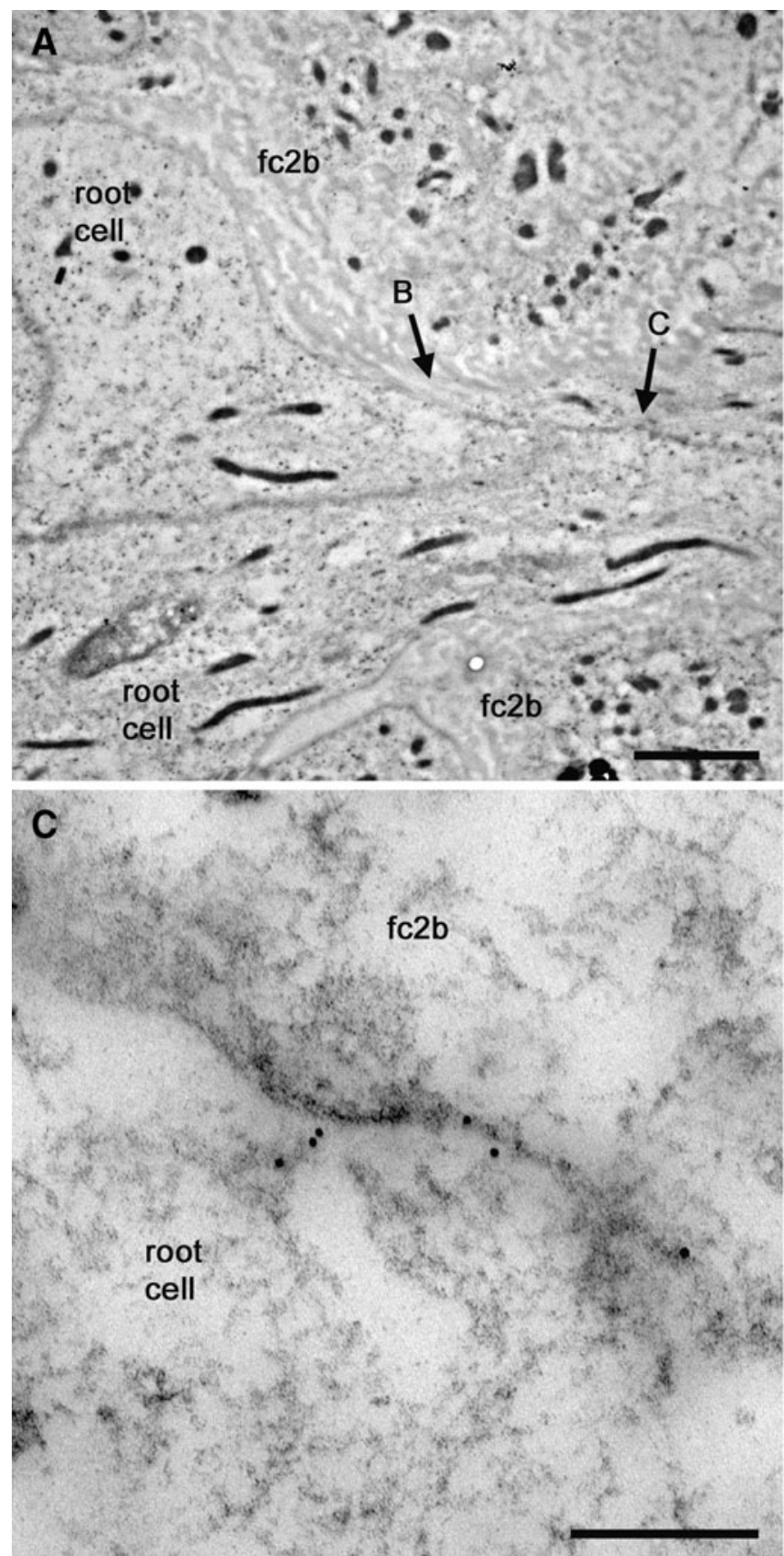

FIG. 8. Kir4.1 immunogold labeling of the root cell process membrane. A Transmission electron micrograph of an $80 \mathrm{~nm}$ section cut from the basal turn cochlear lateral wall, identifying two root cells adjacent to type $2 \mathrm{~b}$ fibrocytes $\left(f_{c} 2 b\right)$. The root cell cytoplasm contained large numbers of elongated mitochondria. B and $\mathbf{C}$ identify the regions detailed below. B Micrograph detailing 10-nm

2002). Siphoning is mediated by electro-neutral $\mathrm{K} / \mathrm{Cl}$ co-transporters (Boettger et al. 2002; Boettger et al. 2003). This transport may be kept energetically favorable by a constant clearance of $\mathrm{K}^{+}$from the Deiters' cell cytoplasm, via an intercellular gap junctional pathway (Jagger and Forge 2006). The supporting cells in the organ of Corti, together with the adjacent epithelial cells spanning the radial distance

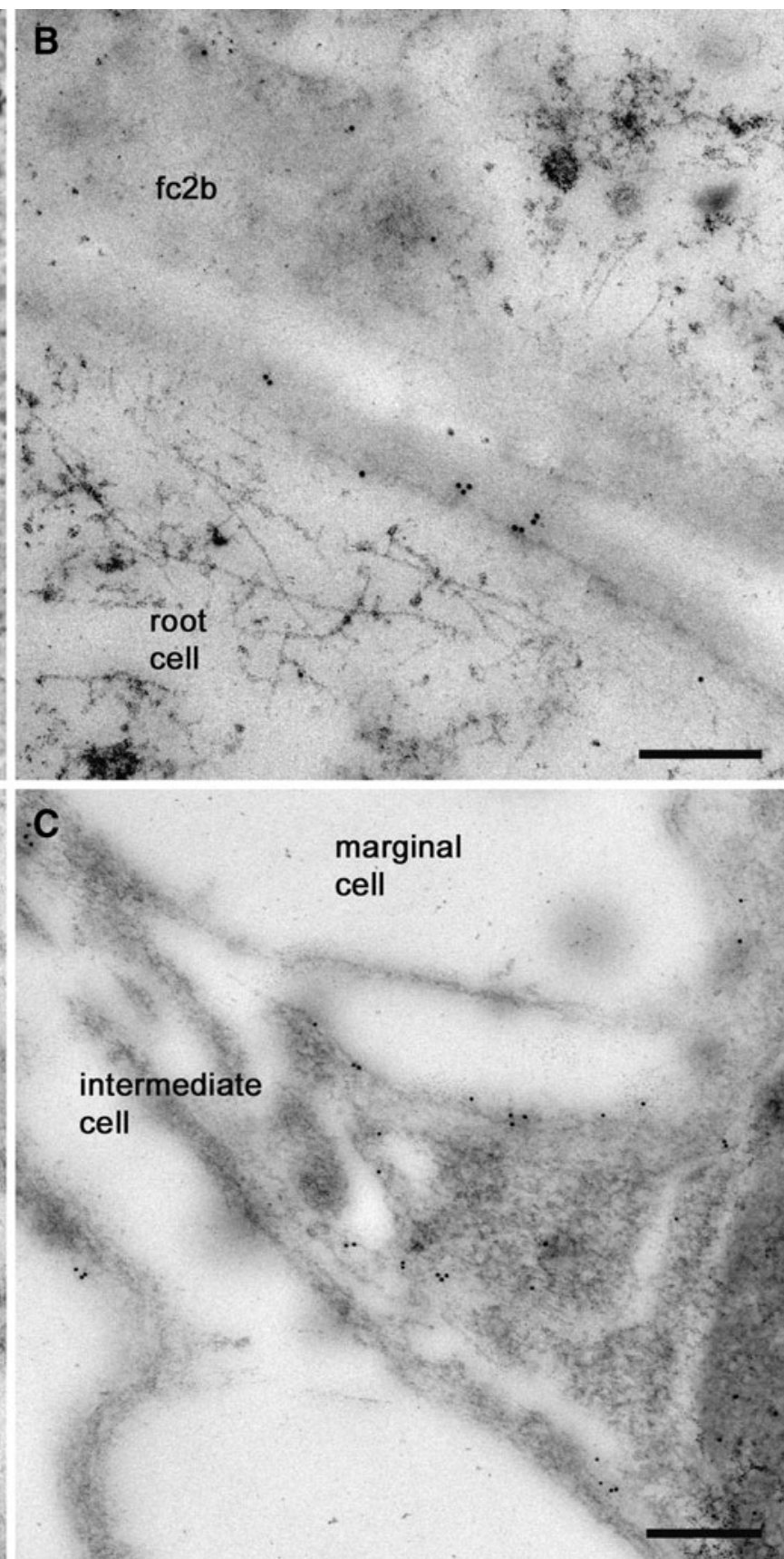

gold particles clustered on the root cell membrane abutting a type $2 \mathrm{~b}$ fibrocyte. Cytoplasmic fibrils were evident in the root cell. C Gold particles labeled the root cell process membrane deeper within the spiral ligament. D Detail of gold particles clustered on the membrane of an intermediate cell process. Particles were not evident within the marginal cell. Scale bars A, $2 \mu \mathrm{m}$; B-D, $0.2 \mu \mathrm{m}$.

to the lateral wall, collectively form a syncytium known as the "epithelial gap junction network" (Kikuchi et al. 2000). Gap junctions in the syncytium are formed from connexin26 (Cx26) and/or Cx30 subunits (Forge et al. 2003a; Forge et al. 2003b; Zhao and Yu 2006). Mutations in the $C x 26$ and $C \times 30$ genes are a common cause of autosomal recessive non-syndromic deafness in humans (Nickel and Forge 2008). In 
mouse models, the deletion of Cx26 or Cx30 from epithelial cells results in hair cell death (CohenSalmon et al. 2002; Teubner et al. 2003). Our dye transfer experiments here showed that the gap junctions between root cells were permeable to Lucifer yellow, a large and negatively charged dye molecule. This permeability suggests that in this region there are mostly homomeric Cx26-containing channels, rather than the homomeric Cx30-containing channels or heteromeric Cx26/Cx30-containing channels that restrict the transfer of Lucifer yellow (Jagger and Forge 2006).

Intercellular coupling within the epithelial gap junction network has been demonstrated in rat cochlear slice preparations, not only in a radial direction (i.e., from the Deiters' cells towards the lateral wall), but also longitudinally along the cochlear partition (Forge et al. 2003b; Jagger and Forge 2006). We have now identified the adjoining root cell system as an additional radial/longitudinal cytoplasmic volume within the epithelial gap junction network. Consequently, we suggest that epithelial cell $\mathrm{K}^{+}$ may be managed by parallel mechanisms, namely (1) recirculation and (2) spatial buffering. Excess $\mathrm{K}^{+}$from acoustically active regions could be recycled radially to the spiral ligament, but could also be dispersed spatially within the longitudinal volume of the epithelial gap junction network, and secreted into the perilymph within less active regions.

\section{Kir4.1 channels may mediate cochlear $\mathrm{K}^{+}$recir- culation}

The weakly inwardly rectifying currents in root cells observed here provide functional evidence in support of the $\mathrm{K}^{+}$recirculation theory. These currents were blocked by millimolar $\mathrm{Ba}^{2+}$, an inhibitor of glial Kir4.1 channels (Connors and Kofuji 2002; Neusch et al. 2006; Neusch et al. 2001). Our immuno-localization of Kir4.1 to root cell processes identifies this channel subunit as the best candidate for transporting $\mathrm{K}^{+}$to the perilymph in the spiral ligament. Other weakly rectifying channels may also contribute to this process, though we have not tested this possibility. Kir4.1 channels display only weak rectification, and permit considerable outward current. This means they would provide $\mathrm{K}^{+}$with an energetically favorable exit from the epithelial network, as proposed for glial cell spatial buffering (Kofuji and Newman 2004). At the predicted resting potential of the epithelial syncytium (slightly depolarized compared to $\mathrm{E}_{\mathrm{K}}$, based on our recordings from groups of root cells), Kir4.1 channels would be constitutively open. The root cell processes would have a large conductance, and $\mathrm{K}^{+}$could efflux to the perilymph down its electrochemical gradient.
Type 2 fibrocytes enveloping the root cell processes express high levels of $\mathrm{Na}, \mathrm{K}-\mathrm{ATPase}$ (Spicer and Schulte 1991) and $\mathrm{Na}-\mathrm{K}-\mathrm{Cl}$ co-transporter (Sakaguchi et al. 1998), and are predicted to transport $\mathrm{K}^{+}$from perilymph into the connective tissue gap junction network (Kikuchi et al. 2000; Wangemann 2006). This remains to be demonstrated directly. The interplay between Kir4.1 and $\mathrm{K}^{+}$transporters is reminiscent of the mechanism employed by stria vascularis to create the high $\left[\mathrm{K}^{+}\right]$in endolymph. Intermediate cells secrete $\mathrm{K}^{+}$via Kir4.1 into the intra-strial space (Ando and Takeuchi 1999; Takeuchi et al. 2000), and $\mathrm{K}^{+}$is pumped subsequently into marginal cells via $\mathrm{Na}, \mathrm{K}-$ ATPase and $\mathrm{Na}-\mathrm{K}-\mathrm{Cl}$ co-transporters ( $\mathrm{Nin}$ et al. 2008; Takeuchi et al. 2000). The Kir4.1-dependent currents in individual guinea pig intermediate cells (Takeuchi et al. 2000) are around ten times larger than we have measured for turn 2 root cells. This difference in channel density between these cell types may explain the lack of detection of root cell Kir4.1 in previous reports localizing this subunit in the lateral wall (Ando and Takeuchi 1999; Hibino et al. 1997).

In addition to its roles in root cells and strial intermediate cells, Kir4.1 subunits have been identified in satellite cells of the spiral ganglion (Hibino et al. 1999; Rozengurt et al. 2003), and in supporting cells in the organ of Corti (Hibino et al. 1997; Rozengurt et al. 2003). The roles of this channel subunit in the cochlea have been studied in Kir4.1 knockout mice. Due to effects beyond the cochlea, Kir4.1 $1^{-/}$mice begin to die at P8 and there is $100 \%$ lethality by P24 (Kofuji et al. 2000). In these mice a number of cochlear tissues display extensive degeneration between P9 and P18 (Rozengurt et al. 2003). By P18 hair cells are absent, the epithelial cell network appears extensively disrupted, and there is a loss of spiral ganglion neurons. Measured between P17-P21, Kir4.1 $1^{-/}$mice do not have an EP, and they have a decreased endolymphatic $\mathrm{K}^{+}$concentration (Marcus et al. 2002). The early lethality, hair cell loss, and the widespread epithelial cell pathology before P18, suggest that it may not be an ideal model to study the role of Kir4.1 in functionally mature root cells.

In guinea pig outer hair cells, basolateral $\mathrm{K}^{+}$ conductance increases around 12-fold from turn 4 to turn 2 (Mammano and Ashmore 1996). This suggests that the maximum load of $\mathrm{K}^{+}$through the epithelial gap junction network to the root cells will increase significantly towards the cochlear base. The numbers and size of individual root cell processes increase towards the basal region, as observed here and elsewhere (Galic and Giebel 1989; Kimura 1984; Spicer and Schulte 1996). The mean current density was more than threefold higher in turn 2 root cells compared to those in turn 4 . Also, type $2 \mathrm{~b}$ fibrocytes, which display specializations for $\mathrm{K}^{+}$reabsorption, 
increase in number towards the basal region of the cochlea (Spicer and Schulte 1996) where intercellular $\mathrm{K}^{+}$fluxes are likely to be greater. Together, these observations provide strong support for the hypothesized co-operation of root cells and fibrocytes to carry out $\mathrm{K}^{+}$recirculation. In addition to $\mathrm{K}^{+}$recirculation, outer sulcus cells in the apical turns may regulate trans-epithelial reabsorption of cations from endolymph to perilymph (Chiba and Marcus 2000). There are large $\mathrm{Ba}^{2+}$-sensitive basolateral $\mathrm{K}^{+}$currents in gerbil apical turn outer sulcus cells (Chiba and Marcus 2001), which may be related to the weakly rectifying $\mathrm{K}^{+}$channels described in the present study.

In summary, our observation of extensive intercellular coupling between root cells extends our understanding of $\mathrm{K}^{+}$buffering in the cochlea. We conclude that Kir4.1 containing channels are expressed in the processes of cochlear root cells, and that these channels may mediate the recirculation of $\mathrm{K}^{+}$from the epithelial gap junction network into perilymph within the spiral ligament. Root-cell-mediated $\mathrm{K}^{+}$ recirculation may support the continuous generation of the endocochlear potential, by ensuring the continuous supply of $\mathrm{K}^{+}$to stria vascularis, and the consequent transduction of acoustic stimuli by hair cells.

\section{ACKNOWLEDGMENTS}

This work was supported by the Biotechnology and Biological Sciences Research Council (Grant BB/D009669/1 to $\mathrm{DJJ}$ and AF), and Deafness Research UK (Grant 358.CAR.DJ to DJ). DJJ is a Royal Society University Research Fellow (Grant 516002.K5746.KK). We thank Jonathan Ashmore and Pavel Mistrik for their valuable advice.

\section{REFERENCES}

ANdo M, TAKeUChI S (1999) Immunological identification of an inward rectifier $\mathrm{K}+$ channel (Kir4.1) in the intermediate cell (melanocyte) of the cochlear stria vascularis of gerbils and rats. Cell Tissue Res 298:179-183

Boettger T, Hubner CA, Maier H, Rust MB, Beck FX, Jentsch TJ (2002) Deafness and renal tubular acidosis in mice lacking the K-Cl co-transporter Kcc4. Nature 416:874-878

Boettger T, Rust MB, Maier H, Seidenbecher T, Schweizer M, Keating DJ, Faulhaber J, Ehmke H, Pfeffer C, Scheel O, Lemcke B, Horst J, Leuwer R, Pape HC, Volkl H, Hubner CA, Jentsch TJ (2003) Loss of K-Cl co-transporter KCC3 causes deafness, neurodegeneration and reduced seizure threshold. Embo J 22:5422-5434

Chiba T, MARcus DC (2000) Nonselective cation and BK channels in apical membrane of outer sulcus epithelial cells. J Membr Biol 174:167-179

Chiba T, Marcus DC (2001) Basolateral K+ conductance establishes driving force for cation absorption by outer sulcus epithelial cells. J Membr Biol 184:101-112

Cohen-Salmon M, Ott T, Michel V, Hardelin JP, Perfettini I, Eybalin M, Wu T, Marcus DC, Wangemann P, Willecke K, Petit C (2002)
Targeted ablation of connexin26 in the inner ear epithelial gap junction network causes hearing impairment and cell death. Curr Biol 12:1106-1111

Connors NC, Kofuji P (2002) Dystrophin Dp71 is critical for the clustered localization of potassium channels in retinal glial cells. J Neurosci 22:4321-4327

Forge A, Becker D, Casalotti S, Edwards J, Marziano N, Nevill G (2003a) Gap junctions in the inner ear: comparison of distribution patterns in different vertebrates and assessement of connexin composition in mammals. J Comp Neurol 467:207-231

Forge A, Marziano NK, Casalotti SO, Becker DL, Jagger D (2003b) The inner ear contains heteromeric channels composed of cx26 and cx30 and deafness-related mutations in cx26 have a dominant negative effect on cx30. Cell Commun Adhes 10:341-346

Galic M, Giebel W (1989) An electron microscopic study of the function of the root cells in the external spiral sulcus of the cochlea. Acta Otolaryngol Suppl 461:1-15

Hibino H, KuRAChi Y (2006) Molecular and physiological bases of the $\mathrm{K}+$ circulation in the mammalian inner ear. Physiology (Bethesda) 21:336-345

Hibino H, Horio Y, Inanobe A, Doi K, Ito M, Yamada M, Gotow T, Uchiyama Y, Kawamura M, Kubo T, Kurachi Y (1997) An ATPdependent inwardly rectifying potassium channel, KAB-2 (Kir4. 1), in cochlear stria vascularis of inner ear: its specific subcellular localization and correlation with the formation of endocochlear potential. J Neurosci 17:4711-4721

Hibino H, Horio Y, Fujita A, Inanobe A, Doi K, Gotow T, Uchiyama Y, Kubo T, KuRACHI Y (1999) Expression of an inwardly rectifying $\mathrm{K}(+)$ channel, Kir4.1, in satellite cells of rat cochlear ganglia. Am J Physiol 277:C638-C644

JAGGER DJ, Forge A (2006) Compartmentalized and signal-selective gap junctional coupling in the hearing cochlea. J Neurosci 26:1260-1268

Johnstone BM, Patuzzi R, Syka J, Sykova E (1989) Stimulus-related potassium changes in the organ of Corti of guinea-pig. J Physiol 408:77-92

Kikuchi T, Kimura RS, Paul DL, Adams JC (1995) Gap junctions in the rat cochlea: immunohistochemical and ultrastructural analysis. Anat Embryol (Berl) 191:101-118

Kikuchi T, Adams JC, Mirabe Y, So E, Kobayashi T (2000) Potassium ion recycling pathway via gap junction systems in the mammalian cochlea and its interruption in hereditary nonsyndromic deafness. Med Electron Microsc 33:51-56

KIMURA RS (1984) Sensory and accessory epithelia of the cochlea. In: Friedmann I, Ballantyne J (eds) Ultrastructural Atlas of the inner ear. Butterworths, London, pp 101-132

Kofuji P, Newman EA (2004) Potassium buffering in the central nervous system. Neuroscience 129:1045-1056

Kofuji P, Ceelen P, Zahs KR, Surbeck LW, Lester HA, Newman EA (2000) Genetic inactivation of an inwardly rectifying potassium channel (Kir4.1 subunit) in mice: phenotypic impact in retina. J Neurosci 20:5733-5740

LiU YP, Zнао HB (2008) Cellular characterization of Connexin26 and Connnexin30 expression in the cochlear lateral wall. Cell Tissue Res 333:395-403

Mammano F, Ashmore JF (1996) Differential expression of outer hair cell potassium currents in the isolated cochlea of the guinea-pig. J Physiol 496(Pt 3):639-646

Marcus DC, Wu T, Wangemann P, Kofuji P (2002) KCNJ10 (Kir4.1) potassium channel knockout abolishes endocochlear potential. Am J Physiol Cell Physiol 282:C403-C407

Mistrik P, Mullaley C, Mammano F, Ashmore J (2009) Three-dimensional current flow in a large-scale model of the cochlea and the mechanism of amplification of sound. J R Soc Interface 6:279-291

Neusch C, Rozengurt N, Jacobs RE, Lester HA, Kofuji P (2001) Kir4.1 potassium channel subunit is crucial for oligodendrocyte development and in vivo myelination. J Neurosci 21:5429-5438 
Neusch C, Papadopoulos N, Muller M, Maletzki I, Winter SM, Hirrlinger J, Handschun M, Bahr M, Richter DW, KirchHofF F, Hulsmann S (2006) Lack of the Kir4.1 channel subunit abolishes $\mathrm{K}+$ buffering properties of astrocytes in the ventral respiratory group: impact on extracellular K+ regulation. J Neurophysiol 95:1843-1852

Nickel R, Forge A (2008) Gap junctions and connexins in the inner ear: their roles in homeostasis and deafness. Curr Opin Otolaryngol Head Neck Surg 16:452-457

Nin F, Hibino H, Doi K, Suzuki T, Hisa Y, Kurachi Y (2008) The endocochlear potential depends on two $\mathrm{K}+$ diffusion potentials and an electrical barrier in the stria vascularis of the inner ear. Proc Natl Acad Sci USA 105:1751-1756

Pujol R, Lenoir M, Ladrech S, Tribillac S, Rebillard G (1992) Correlation between the length of outer hair cells and the frequency coding of the cochlea. In: Cazals Y, Demeny L, Horner K (eds) Auditory physiology and perception. Pergamon, Oxford, pp 45-52

Rozengurt N, Lopez I, Chiu CS, Kofuji P, Lester HA, Neusch C (2003) Time course of inner ear degeneration and deafness in mice lacking the Kir4.1 potassium channel subunit. Hear Res 177:7180

Sakaguchi N, Crouch JJ, Lytle C, Schulte BA (1998) Na-K-Cl cotransporter expression in the developing and senescent gerbil cochlea. Hear Res 118:114-122

SOUter M, Forge A (1998) Intercellular junctional maturation in the stria vascularis: possible association with onset and rise of endocochlear potential. Hear Res 119:81-95
Spicer SS, Schulte BA (1991) Differentiation of inner ear fibrocytes according to their ion transport related activity. Hear Res 56:5364

Spicer SS, Schulte BA (1996) The fine structure of spiral ligament cells relates to ion return to the stria and varies with placefrequency. Hear Res 100:80-100

Takeuchi S, Ando M, Kakigi A (2000) Mechanism generating endocochlear potential: role played by intermediate cells in stria vascularis. Biophys J 79:2572-2582

Teubner B, Michel V, Pesch J, Lautermann J, Cohen-Salmon M, Sohl G, Jahnke K, Winterhager E, Herberhold C, Hardelin JP, Petit C, Willecke K (2003) Connexin30 (Gjb6)-deficiency causes severe hearing impairment and lack of endocochlear potential. Hum Mol Genet 12:13-21

Wada J, Kambayashi J, Marcus DC, Thalmann R (1979) Vascular perfusion of the cochlea: effect of potassium-free and rubidiumsubstituted media. Arch Oto-rhino-laryngol 225:79-81

WANGEMANN P (2006) Supporting sensory transduction: cochlear fluid homeostasis and the endocochlear potential. J Physiol 576:11-21

Weber PC, Cunningham CD 3RD, Schulte BA (2001) Potassium recycling pathways in the human cochlea. Laryngoscope 111:1156-1165

ZhaO HB, YU N (2006) Distinct and gradient distributions of connexin26 and connexin30 in the cochlear sensory epithelium of guinea pigs. J Comp Neurol 499:506-518

Zhao HB, Kikuchi T, Ngezahayo A, White TW (2006) Gap junctions and cochlear homeostasis. J Membr Biol 209:177-186 